\title{
General Enterprising Tendencies amongst Grade Ten Learners of Limpopo Province, Capricorn District Municipality
}

\author{
Kgahliso Maoto \\ Department of Business Management, University of Limpopo, Turfloop Campus, South Africa \\ maotomk@webmail.co.za \\ Prof JT Van Niekerk \\ Department of Business Management, University of Limpopo, Turfloop Campus, South Africa \\ trevor.vanniekerk@ul.ac.za
}

\section{Doi:10.5901/mjss.2014.v5n27p184}

\begin{abstract}
This study sought to assess the general enterprising qualities such as need for achievement, need for autonomy, creative tendency, calculated risk taking as well as drive and determination amongst learners at selected secondary schools in the Capricorn District Municipality (CDM), Limpopo Province of South Africa. The intention was to suggest strategies to be used to enhance entrepreneurial qualities and to develop these learners to become successful entrepreneurs. The population of the study consisted of 6214 grade ten learners doing commercial subjects and those not doing commercial subjects, from randomly selected circuits, in CDM. In total, 1931 respondents, which constituted 31\% of the population, were sampled and participated in the research study. The findings revealed that the majority of the learners did not possess entrepreneurial qualities. The results obtained from learners who participated in the study, displayed ability for need for achievement and calculated risk taking. However, their performances in other categories were below $50 \%$ which is a clear indication of a lack of ability in respects of: need for autonomy; creative tendency as well as drive and determination. This study unveil the entrepreneurial qualities of learners in secondary schools and particularly focuses on grade ten learners, because they are at secondary school level where they have to select subjects of their choice which could affect their future education and development. Furthermore, grade ten learners were selected, because they are less explored in a South African context.
\end{abstract}

Keywords: entrepreneurship, entrepreneur, entrepreneurship education and Limpopo Province.

\section{Introduction}

Entrepreneurs have an important effect on the economy by establishing new businesses that provide not only goods and services to customers, but also job opportunities for individuals in various industries. Both entrepreneurship and the entrepreneur ensure growth in the economy. Entrepreneurs are the drivers of business and create value for themselves and the society as a whole (Hisrich \& Peters, 2002). Venter, Ubarn and Rwigema (2008) mention that growth in respect of the number of entrepreneurs in both the formal and informal sectors reflects the accelerated growth rate experienced by the South African economy. South Africa's Total Entrepreneurial Activity (TEA) rate is dominated by necessity entrepreneurs with low expectations of growth and job creation (Autio, 2007). Necessity entrepreneurs are involved in entrepreneurial efforts, because they have no other choice; returns are low and intermittent and motivation is personal survival. Many South Africans are making a living out of the informal sector. Without a steady supply of entrepreneurs, South Africa is likely to stagnate and deteriorate economically. Entrepreneurial ventures have served as South Africa's economic bedrock. Nowadays, the economic growth of nations is intertwined with the volume and caliber of its entrepreneurs. Venter et al (2008) indicate that the success of entrepreneurs will determine South Africa's job creation and growth potential. They postulate that entrepreneurship is relevant to government departments, parastatals, the arts, non- governmental organization (NGOs), farmers, informal businesses, and other pursuits. Today, entrepreneurs are considered to be the heroes of free enterprise since innovation and creativity have helped many to build large enterprises from small business. In reality, they are those who, through hard work and long hours, generate business success (Van Aardt, Hewitt, Bendeman, Bezuidenhout, Janse van Rensburg, Naidoo, Van Aardt, Van der Bank \& Visser, 2011).

Entrepreneurship education should endeavour to provide students with knowledge, skills and motivation to encourage entrepreneurial success in a variety of settings (Davidsson, 2008). According to Timmons and Spinelli (2006), 
entrepreneurship is a way of thinking, reasoning and acting that is opportunity obsessed, holistic in approach, and leadership balanced. Entrepreneurship results in the creation, enhancement, realisation, and renewal of value, not just for owners, but for all participants and stakeholder. Venter et al (2008) indicate that in South Africa, entrepreneurial education is partially institutionalised as part of the new outcomes-based education(OBE) school curriculum; and entrepreneurial education forms part of academic offerings at several higher education institution. Identifying business opportunities and having confidence in personal skills to implement a business may be enhanced through education and training. The evidence suggests that those with advanced education are more likely to pursue opportunity entrepreneurship, which may have overall benefits for national growth (Raynolds, Bygrave \& Autio, 2003).

The research was conducted in Capricorn District Municipality (CDM) of the Limpopo Province of the Republic of South Africa. Limpopo Province is one of the nine provinces which are characterised by high levels of unemployment, poverty, escalating crime, xenophobic attacks, child abuse, a fast spread of HIVIAIDS infection amongst youth as well as a huge number of illiterate people. Above all, a low matriculation pass rate. This province is divided into five District Municipalities namely: Vhembe, Greater Sekhukhune, Capricorn, Mopani and Waterberg of which Capricorn District Municipality is further divided into 32 circuits. From these circuits, ten circuits were selected for the purpose of this study. This study intends to contribute knowledge and guidelines on entrepreneurship development at secondary schools within the CDM of Limpopo Province. It also intends to contribute knowledge and guidelines on entrepreneurship development at secondary schools within the CDM of Limpopo Province.

An adopted questionnaire from Caird (1992) was used to collect primary data from grade ten learners with the purpose of comparing those who were enrolled for commercial subjects with those who were not enrolled for commercial subjects. The questionnaire was constructed to determine the entrepreneurial qualities of grade ten learners at large. It also aimed at assessing their general enterprising tendencies (entrepreneurial qualities) such as the need for achievement, need for autonomy, creative tendency, calculated risk taking as well as drive and determination. However, the focus of the study was grade ten learners at selected secondary schools in the Capricorn District Municipality of Limpopo Province. The intention was to suggest strategies to be used at secondary schools to enhance entrepreneurial qualities amongst secondary school learners and to develop these learners to become successful entrepreneurs with the inspiration to start their own businesses in future.

\section{Literature Review}

This section reflects secondary data exploited to acquaint the study with the characteristics of entrepreneurs, entrepreneurial motivation, entrepreneurship education, and the benefits of entrepreneurship education.

\subsection{Characteristics of entrepreneurs}

Van Aardt et al (2011) indicate that a vast number of research have been undertaken to identify the characteristics of successful entrepreneurs, and to date, no single research has been able to pinpoint the exact personality traits that will predict whether or not one will be successful as an entrepreneur. They have mentioned 'big five' personality dimensions of entrepreneurs as described by (Stokes \& Wilson, 2010a): need to achieve; need for autonomy; internal locus of control; calculated risk taking; and entrepreneurial self-efficacy. These factors were also supported by (Nieman, Hough \& Niewenhuizen, 2003; Wickham, 2004; Morris \& Kuratko, 2002; Hisrich \& Peters, 2002; Wickham, 2001). In addition to the big five characteristics, Baum, Locke, and Smith (2001) identified the following traits:

- Tenacity > entrepreneurs do not give up.

- Proactivity > entrepreneurs plan ahead.

- Passion for work > entrepreneurs believe in what they are doing and are passionate about their ventures.

- Opportunism > entrepreneurs can identify opportunities and act on them.

- Vision > entrepreneurs have visions of what they want to achieve and how they want to do it.

- Dynamism > entrepreneurs are go-getters and are energetic.

\subsection{Entrepreneurial motivation}

Rwigema and Venter (2004) indicate that entrepreneurs are motivated to start their own businesses for various reasons which are categorised as pull and push factors. They postulate the following pull factors: profit motive; challenge; and desire for independence. According to Co, Groenewald, Mitchell, Nayager, Van Zyl, Visser, Train and Emanual (2006) 
entrepreneurs have the freedom and independence to take any decision for their businesses, which means they are in charge of them. These authors are of opinion that the feeling of being your own boss and being in control of your own business makes most entrepreneurs happy and satisfied.

Due to the current situation in South Africa, most of the people follow entrepreneurship as a career choice because of desperation of work e.g. retrenchment and early age pension as well as a high level of unemployment, they become entrepreneurs as a matter of necessity in order to make a living. This situation is painful and not desirable at all. Among others, the following are regarded as push factors: unemployment; job insecurity; disagreement with management, career limitations and setbacks in a conventional job; negative displacement or having no other alternative; social misfits; limitation of financial rewards; and misfit within the organization (Wickham, 2004; Davidsson, 2008; Nieman, Hough \& Niewenhuizen, 2003; Bjerke, 2007).

\subsection{Entrepreneurship education}

Davidssons (2008) states that entrepreneurship education seeks to provide students with knowledge, skills and motivation to encourage entrepreneurial success in a variety of settings. He also shows that entrepreneurship education focuses on the realization of opportunities, while management education is focused on the best way to operate existing hierarchies. Bjerke (2007) adds that entrepreneurship education helps to decrease the chances of failure by stressing a consistent and proven set of practices.

\subsection{Benefits of entrepreneurship education: benefits to secondary school learners}

Entrepreneurship education can positively impact on learners at secondary levels in a large number of contexts. Consortium for entrepreneurship education (2004) explains why there is such a wide variety of entrepreneurship programmes, all of which can provide crucial outcomes at different stages of the learner's life, such as:

- Developing the ability to prepare a business plan.

- Applying economic principles, basic accounting principles, and basic marketing skills.

- Using strategies for idea generation, assessing feasibility of ideas, translating problems into opportunities and engaging in ethical business practices.

- Determining individual entrepreneurial interest.

- Identifying legitimate sources of capital, demonstrating financial management and speaking "business" and "entrepreneurship".

- Managing risk and being able to apply the principles of human relations management.

- Evaluating ownership structures.

\subsection{Relevance of entrepreneurship in South Africa}

According to Venter, Urban and Rwigema (2008) entrepreneurship is associated with facilitating national economic growth, creation of new ventures, re-orientation of existing business toward more entrepreneurial goals, and even the redirection of national institutional infrastructure. According to them South Africa's entrepreneurs played, and continue to play a seminal role in economic vitality. They mention the following names: Oppenheimer (mining and numerous other fields); Donald Gordon (insurance); and Anton Rupert (tobacco and luxury goods), as looming large in the annals of South African entrepreneurship.

Venter et al postulated that through decades, entrepreneurial organisations have inspired and funded myriad startups. Cumulatively, entrepreneurial ventures have served as South Africa's economic bedrock. Nowadays, the economic growth of nations is intertwined with the volume and caliber of its entrepreneurs. Innovative start-ups create wealth that trickles into the general economy, triggering secondary growth. Venter et al (2008) state that the profile shows how Raymond Ackerman transformed four retail stores into South Africa's largest chain and how Herman Mashaba founded and grew Black Like Me against all odds into a vibrant producer of niche cosmetics. They further, postulate that these examples illustrate a general point that high growth ventures may have modest origins, but with a strong-minded, inventive entrepreneur behind them; they can have tremendous lasting impact on economic growth and job creation in a country where unemployment, poverty, and inequality are rife.

Venter et al (2008) indicate that the success of entrepreneurs will determine South Africa's job creation and growth potential. They suggested that entrepreneurship is relevant to government departments, parastatals, the arts, non- 
governmental organization (NGOs), farmers, informal businesses, and other pursuits. In an increasingly globalised world, survival depends on people who are driven by opportunity and who seek to maximize their goals in a sustainable way. They further mention that entrepreneurship has social and economic dimension.

\subsubsection{Entrepreneurship and job creation}

South African Survey, 2006/2007 quoted by Venter et al (2008) postulate that in South Africa, the role of small business is pivotal. They mention that the growth and development of the small and micro enterprise business sector has identified many stakeholders as being of the utmost importance in an effort to create employment and address poverty.

Venter et al (2008) mention that growth in respect of a number of entrepreneurs in both the formal and informal sectors reflects the accelerated growth rate experienced by the South African economy. South Africa's Total Entrepreneurial Activity (TEA) rate is dominated by necessity entrepreneurs with low expectations of growth and job creation (Autio, 2007). Necessity entrepreneurs are involved in an entrepreneurial efforts because they have no other choice; returns are low and intermittent and motivation is personal survival. Many South Africans are making a living out of the informal sector. They emphasise that few small-scale businesses may grow into giants with a disproportionate impact on employment and wealth creation. Without a steady supply of entrepreneurs, South Africa is likely to stagnate and deteriorate economically.

\subsubsection{Entrepreneurship and education}

Venter et al (2008) show that in South Africa, entrepreneurial education is partially institutionalised as part of the new outcomes-based education (OBE) school curriculum; and entrepreneurial education forms part of academic offerings at several higher education institutions. In industrialised countries, entire schools exist for entrepreneurship. With the spread of capitalism and globalisation, entrepreneurship continues to gain importance and this trend is also gaining momentum in South Africa (SA). Globalisation exposes entrepreneurs everywhere to merciless competition (actual and potential) from 190-odd countries (Niewenhuizen, 2008). As tariffs reduce and trading straddles national borders, survival will depend upon the creativity and resilience of South Arica's entrepreneurs.

Variation in levels of entrepreneurship can be explained in that individuals with more education and from households with higher incomes are more likely to pursue opportunity entrepreneurship (high-growth venture) than those with less education and from poor households who are more likely to pursue necessity entrepreneurship (survivalist venture).

Education has a positive impact on the greater post-secondary educational activity and on increase in opportunity entrepreneurship. Identifying business opportunities and having confidence in personal skills to implement a business may be enhanced through education and training. The evidence suggests that those with advanced education are more likely to pursue opportunity entrepreneurship, which may have overall benefits for national growth (Raynolds, Bygrave \& Autio, 2003).

Entrepreneurial education is growing fast not only in the United State of America (US) and Europe but also in South Africa with the number of schools in the hundreds, and dozens of programmes offered by top business schools at graduate and undergraduate levels. Katz (2003) states that there are too many academics, too much established infrastructure and too much demand from students, organizations and governments to let entrepreneurship fall into disuse or disarray.

\subsubsection{Entrepreneurship in government and parastatals}

Venter et al (2008) postulate that entrepreneurship is commonly discussed in the context of private business; however, government departments, parastatals, and other organs need to think and act entrepreneurially. They mentioned that in government, one is used to lumbering bureaucracies, funded from the public tax revenue and often deaf to public services. Government departments, parastatals, and other organs' mission are largely undefined or unfulfilled. Instead, it is replaced with inordinate reverence for rules and procedures, and contempt for civilian concerns. Venter et al (2008) indicated that this depiction is admittedly overstated and stereotypical, but, nonetheless, largely true. Organizations such as parastatals are condemned to permanent dependence on public funding because they create little value and eschew innovation in the face of changing times.

They further postulate that in South Africa and internationally, government departments face shrinking budgets and growing public expectations. As a result, government departments have to compete for legitimacy and funding in the 
same market as private organizations and non-governmental organizations. For these organizations to survive, they should act entrepreneurially with the hope of staying competitive. Essentially, they need to identify and acquire entrepreneurial skills with which to turn their organization around. Venter et al recommend to these organizations that the integration of opportunity, resources and a dynamic team applies every bit as strongly as it does in the private sector. Activity similar to that in government is occurring in parastatals such as Eskom, Telkom, Transnet and others who are facing unprecedented competition. The trend will culminate in the reorientation of the public sector along basic entrepreneurial principles.

Venter et al (2008) indicate that turning these organizations around; involve a change of culture, which takes time. However, it is possible to predict with some confidence that winners will emerge from among those who choose the entrepreneurial path rather than dig in their heels.

\subsubsection{Entrepreneurship in NGOs and social entrepreneurs}

Venter et al (2008) indicate that during post-1994, many found themselves without a cause, and folded. Others underwent transformational change to survive in this brave new world. Success has varied, as it has in the business sector, but many are flourishing, e.g. IDASA (the Independence Democratic Association of South Africa) has moved on to greener pastures as political analysts and development experts. They sought and developed new opportunities. Over the last decade, a critical mass of foundation and non-profit organizations has emerged. Perado and Chrisman, (2006) quoted by Venter et al (2008) indicate that worldwide policy-makers were using the language of local capacity building as a strategy to assist impoverished communities to become self-reliant. They mention that social entrepreneurs are reformers and revolutionaries and they affect fundamental changes in the way things are done in the social sector.

Venter et al (2008) perceive social entrepreneurs as mission-based businesses rather than as charities; they seek to create systematic changes and sustainable improvement, and they take risks on behalf of the people and organizations they serve. These people may act locally; their actions have the potential to stimulate global improvements in different fields, whether education, health care, economic development, the environment, the arts or any other social fields.

\subsubsection{Entrepreneurship in politics}

Venter et al (2008) postulate that the impact of change and the need for entrepreneurship is pertinent in education, sport, charity work, law- virtually every aspect of life, including politics. Those who analyse the situation accurately and reposition strategically, change the odds in their favour. In every threat lies an opportunity. Voters can be fickle and parties that take them for granted may find themselves without an electorate. They indicate that certain South African parties have shrunk to the verge of extinction in only nine years. A case in point is the Pan African Congress (PAC). Particularly after the departure of Patricia de Lille, the party is having no apparent strategy and weak leadership. By contrast, the African National Congress (ANC) appears to have refocused itself from merely opposing apartheid to running a modern state.

Venter et al (2008) indicate that in the United State and other industrialized western nations, parties are run on business principles, parlaying their leaders as marketable 'products'. Different South African political parties are trying to reposition themselves in a post-democratic world as new opportunities and danger arises. Those organisations and politicians who continually apply entrepreneurial skills may weather the storm much more easily than those who cling to the status quo. Entrepreneurial leadership remains relevant in the political arena, non-profit organisations, social and cultural ventures, and in other areas. They regard entrepreneurship as pertinent to every endeavour and its principles may apply wherever people aspire to manage change.

\subsubsection{Entrepreneurship in the arts}

The legacy of great artists is their work. The ability of some artists to exploit the far more limited opportunities that were available to them in order that they might utilise and exploit their natural gifts and talent - is testimony to the fact that many artists do possess a number of critically important entrepreneur character themes. They would have to look for commissions and patrons who demanded networking skills and emotional intelligence. In reality, many of them had to overcome a wide range of obstacles, especially the envy and hostility of their rivals, in order to pursue and complete their work indicating the presence of ego, dedication and courage. Most great artists are the ones that surpass what is currently accepted as great art and innovative to create a new art form (Venter et al, 2008). 
Many did not attain wealth when they were alive-although some of them did become wealthy, but it seems achievement was the driving motive that led them to overcome material poverty and mental anguish to pursue their art (Bolton \& Thompson, 2004).

\section{Research Methodology}

\subsection{Participants}

This study invited 1931 grade ten learners, 51\% females and $49 \%$ males, from ten selected secondary schools in the Capricorn district municipality of Limpopo Province, South Africa to participate in the study. The average age of learners ranged from 13 to 19 years, although those who were above nineteen were also allowed to take part. The participants consisted of two groups, namely learners enrolled for commercial subjects and learners not enrolled for commercial subjects.

\subsection{Instrument}

The instrument used in this study was a questionnaire; "the most common method of collecting survey data" (Crouch \& Housden, 2003). The questionnaire assesses learners on how they performed in respect of five entrepreneurial qualities, namely: need for achievement; need for autonomy; creative tendency; calculated risk taking; and drive and determination. The performance of learners was classified as adequate ability, moderate ability and lack of ability. Fifty four statements, captured in the questionnaire, were divided into five categories each of which represented particular entrepreneurial qualities. The first group, need for achievement, embraced statements 1, 10, 15, 19, 24, 28, 33, 37, 42, 46, and 51. The second group, need for autonomy, included statements 3,12,21,30,39, and 48. The third group, creative tendency, covered statements 5, 8, 14, 17, 23, 26, 32, 35, 41, 44, 50, and 53. Statements 2, 9, 11, 20, 27, 29, 36, 38, 45, 47, and 54 expressed the learner's ability to take a calculated risk, while the last group, drive and determination, included statements $4,7,13,16,22,25,31,34,40,43,49$, and 52 . The respondents were required to indicate whether they agree or disagree with each statement in each of the five categories. A high score on the scale indicated a positive opinion and vice versa, a low score on the scale indicated a negative opinion whereas an average score indicated average opinion.

The data were analysed using the Statistical Package for the Social Sciences (SPSS Version 16.0 for Windows). The data which were collected through the Questionnaire from Caird (1992) were subjected to descriptive statistics as well as excel for data capturing.

\subsection{Data management and analysis}

From the collected data obtained from grade ten learners at selected secondary schools from various selected circuits in $\mathrm{CDM}$, the researcher started by giving each questionnaire a code ranging from code one to the last questionnaire which was given code one thousand nine hundred and thirty one. Thereafter, she captured that information using Statistical Package for the Social Sciences (SPPS) where she again gave each question's answer a code, e.g. in section A of the questionnaire relating questions to demographics, all males were given a code of one and all females a code of two. In section B, codes were given to all answers related to entrepreneurial qualities. Since section B comprises of dichotomous answers which is agree or disagree, agree was given a code of one and disagree a code of two. Missing values and wrongly coded data were scrutinise and cleaned by using descriptive statistics, frequencies of variables as well as cross tabulation, and exported to Microsoft Excel in order to draw figures and tables.

In order to calculate the scores obtained in each entrepreneurial quality question, information was transformed and all variables were computed and related to each quality and thereafter descriptive statistics, cross tabulation, were used and then exported to Microsoft Excel to construct histograms and tables. The information was analysed using pie charts, histograms, as well as tables. The information in tables was presented in numbers and percentages while information in pie charts and histograms was presented in percentages only.

\subsubsection{The Questionnaire}

The questionnaire comprised two sections, namely: Section A for the collection of demographic information. This section required the respondents to provide information about themselves e.g. on the issue of gender and age group, while section B gathered data related to entrepreneurial qualities such as need for achievement, need for independence, 
creative tendencies, calculated risk taking and drive and determination.

Section B

- $\quad$ Need for Achievement:

The respondents that scored well in this section had many, if not all, of the following qualities: being forwardlooking; self-sufficient, optimistic rather than pessimistic; task-oriented, results-oriented, restless, energetic; self-confident; persistent; and determined and dedicated to complete a task. The maximum score in this section is 12, average 8 and minimum less than 8 . The following questions, captured in the questionnaire, assessed the need for achievement:

(1) I would not mind routine unchallenging work if the pay and pension prospects were good.

(6) I find it difficult to switch off from work completely.

(10) I like challenges that stretch my abilities and get bored with things I can do quite easily.

(15) If I am having problems with a task I leave it, forget it and move on to something else.

(19) I think more of the present and past than of the future.

(24) It is more important to do a job well than to try to please people.

(28) I get annoyed if people are not on time for meetings.

(33) I would rather work with a person I liked who was not good at the job, rather than work with someone I did not like even if they were good at the job.

(37) I would rather work on a task as part of a team rather than take responsibility for it myself.

(42) When I am faced with a challenge I think more about the results of succeeding than the effects of failing.

(46) I get up early, stay late or skip meals if I have a deadline for some work that needs to be done.

(51) I find it easy to relax on holiday and forget about work.

Those learners that showed a strong need for achievement disagreed with the statements in questions 1 , 15,19,33,37 and 51 and agreed with the other six statements, namely 6, 10,24,28,42 and 46.

- Need for Autonomy/ Independence:

The respondents who scored well in this section likes to do unconventional things, prefers working alone, needs to do his or her own things, needs to express what he or she thinks, dislikes taking orders, likes to make up his or her own mind, does not bow to group pressure and is stubborn and determined. The maximum score in this category is 6 , average 4 and minimum less than 4 . There were six questions that measured need for autonomy or independence, namely:

(3) I tend not to like to stand out or be unconventional.

(12) At work, I often take over projects and steer them my way without worrying about what other people think.

(21) I like a lot of guidance to be really clear about what to do at work.

(30) I rarely need or want any assistance and like to put my own stamp on work that I do.

(39) I usually do what is expected of me and follow instructions carefully.

(48) I get annoyed if superiors or colleagues take credit for my work.

The respondents that showed a need for autonomy or independence agreed with the statements in questions12, 30 and 48 and disagreed with the statements in questions 3, 21, and 39.

- Creative tendency:

A high score in this section implies that the respondent is imaginative and innovative, has a tendency to day dream, is versatile and curious, has lots of ideas and enjoys novelty, new challenges and changes. In this section a respondent can score a maximum of 12, an average of 8 and minimum of less than 8 .

The following questions tested creativity tendency:

(5) I rarely day dream.

(8) Sometimes people find my ideas unusual.

(14) Sometimes I think about information almost obsessively until I come up with new ideas and solutions.

(17) I do not like unexpected changes to my weekly routines.

(23) I am wary of new ideas, gadgets and technologies.

(26) Other people think that I'm always making changes and trying out new ideas.

(32) I prefer to be quite good at several things rather than very good at one thing.

(35) I prefer doing things in the usual way rather than trying out new methods.

(41) I like to have my life organised so that it runs smoothly and to plan.

(44) I like to spend time with people who have different ways of thinking.

(50) Sometimes I have so many ideas that I feel pressurised.

(53) It is harder for me to adapt to change than keep to a routine. 
In this section a maximum score could be obtained by agreeing with questions $8,14,26,32,44$ and 50 and disagreeing with questions, 5, 17,23,35,41 and 53 .

- Calculated risk taking:

If one did well here, it means that they have acted on incomplete information, judges when incomplete data are presented, accurately assesses his or her own capabilities, is rather over and under ambitious, evaluates and sets challenging but attainable goals. This category has a maximum score of 12 , an average of 8 and minimum of less than 8.

The questions that determine calculated risk taking were:

(2) I like to test boundaries and get into areas where few have worked before.

(9) I would rather buy a lottery ticket than enter a competition.

(11) I would prefer to have a moderate income in a secure job rather than a high income in a job that depended on my performance.

(18) If I wanted to achieve something and the chances of success were 50/50, I would take the risk.

(20) If I had a good idea for making some money, I would be willing to invest my time and borrow money to enable me to do it.

(27) If there is a chance of failure I would rather not do it.

(29) Before I make a decision I like to have all the facts no matter how long it takes.

(36) Before making an important decision I prefer to weigh up the pro's and con's fairly quickly rather than spending long time thinking about it.

(38) I would rather take an opportunity that might lead to even better things than have an experience that I am sure to enjoy.

(45) I find it difficult to ask for favours from other people.

(47) What we are used to is usually better than what is unfamiliar.

(54) I like to start interesting projects even if there is no guaranteed payback for the money or time I have to put in.

From all these questions a maximum score could be obtained by disagreeing with questions $9,11,27,29,45$ and 47 and agreeing with questions,2,18,20,36,38 and 54 .

- Drive and Determination:

If the respondent had done well in this section, he or she tends to take advantage of opportunities, discounts, fate, makes his or her own luck, is self-confident, believes in controlling his or her own destiny, equates results with efforts and shows considerable determination. This section has a maximum score of 12 , an average of 8 and minimum of less than 8 .

The questions that determine drive and determination were:

(4) Capable people who fail to become successful have not usually taken chances when they have occurred.

(7) You are either naturally good at something or you are not, effort makes no difference.

(13) Many of the bad times that people experience are due to bad luck.

(16) When I make plans I nearly always achieve them.

(22) People generally get what they deserve.

(25) I try to accept that things happen to me in life for a reason.

(31) You are not likely to be successful unless you are in the right place at the right time.

(34) Being successful is a result of working hard, luck has little to do with it.

(40) For me, getting what I want is a just reward for my efforts.

(43) I believe that destiny determines what happens to me in life.

(49) People's failures are rarely the result of their poor judgement.

(52) I get what I want from life because I work hard to make it happen.

Agreeing with questions, 4, 16,22,34,40 and 52 and disagreeing with questions 7, 13,25,31,43 and 49 is an indication of drive and determination.

\section{Findings and Discussions}

\subsection{Overall summary of the findings in respect of the entrepreneurial qualities of respondents}

This section presents and analyses the responses of the respondents regarding their entrepreneurial qualities. The scores for their entrepreneurial qualities were divided into three categories, namely, adequate ability, moderate ability and 
lack of ability. The results are presented in both numbers and percentages. The responses provided by learners, gave a clear indication about their need for achievement, need for autonomy, calculated risk-taking, creative tendencies as well as drive and determination.

For the purpose of this research, the focus was on the qualities that contributed to determine whether a person has entrepreneurial abilities. Table 4.1 and figure 4.1 offers a summary of grade ten learners tested for entrepreneurial qualities in the CDMs of Limpopo Province.

Table 4.1: Summary of the entrepreneurial qualities of respondents

\begin{tabular}{|l|c|c|c|c|}
\hline $\begin{array}{l}\text { Entrepreneurial } \\
\text { qualities }\end{array}$ & Adequate ability & Moderate ability & Lack of ability & Total \\
\hline Need for achievement & $641(33.2 \%)$ & $373(19.3 \%)$ & $917(47.5 \%)$ & $1931(100 \%)$ \\
\hline Need for autonomy & $70(3.7 \%)$ & $316(16.8 \%)$ & $1496(79.5 \%)$ & $1882(100 \%)$ \\
\hline Creative tendency & $377(19.5 \%)$ & $427(22.1 \%)$ & $1127(58.4 \%)$ & $1931(100 \%)$ \\
\hline Calculated risk taking & $588(30.4 \%)$ & $459(23.8 \%)$ & $884(45.8 \%)$ & $1931(100 \%)$ \\
\hline Drive and determination & $251(13 \%)$ & $373(19.3 \%)$ & $1307(67.7 \%)$ & $1931(100 \%)$ \\
\hline
\end{tabular}

Source: Researcher's own findings

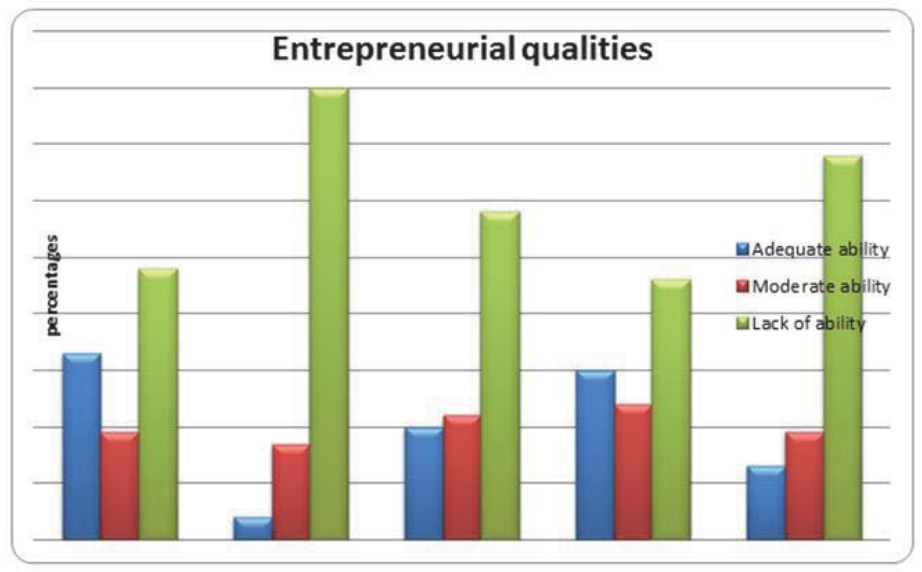

Figure 4.1: Summary of the entrepreneurial qualities of the respondents

Source: Researcher's own findings

\subsubsection{Need for achievement}

According to Wickham (2001) entrepreneurs are competitive in nature, set challenging and dynamic goals for themselves and, on top of that, they want to excel and achieve.

He also notes that entrepreneurs are self-starters who are driven internally and have a strong desire to compete against self-imposed standards and challenging goals they set for themselves.

According to table 4.1 , the results revealed that only $33,2 \%$ of the grade ten learners, when measured for achievement, displayed an adequate ability to achieve. The vast majority of the learners that were tested for need for achievement displayed a lack of ability, $47,5 \%$ and a moderate ability, 19,3\%. However, combining adequate and moderate abilities revealed that $52,5 \%$ of the respondents displayed ability for need for achievement while $47,5 \%$ did not have the ability to achieve.

\subsubsection{Need for autonomy/independence}

Wickham (2004) mentions that entrepreneurs should have a need for independence, in other words, they aspire to be their own bosses; they do not like to be tied up with rules and regulations from others. According to Nieman et al (2003), 
"to be one's own boss is one of the biggest reasons why people become entrepreneurs. They are tired of working for somebody else and, therefore, establish their own ventures."

Again, table 4.1 reflects that only $3,7 \%$ of the grade ten learners tested, displayed an adequate ability for need for autonomy, while 16, $8 \%$ displayed a moderate ability. Combining these two categories revealed that only $20,5 \%$ of respondents displayed the ability to be autonomous and independent. However, $79,5 \%$ of the respondents tested, lack the ability in terms of skills required for a person to operate independently and to become his or her own boss.

\subsubsection{Creative tendency}

Morris and Kuratko (2002) express creativity as the development of new and uncommon ideas for products and services, while innovation refers to the conversion of these new ideas into marketable products and services. They also believe that everybody is capable of being creative, but it is just a matter of how individuals develop the creativity within themselves to produce favourable results. This perception is supported by Nieuwenhuizen (2004) stating that: "creativity is a person's imagination and his/her ability to think of something original."

Hisrich and Peters (2002) support this statement, indicating that innovation is a crucial aspect of the entrepreneurial process. They remark that the entrepreneur's task go beyond simply inventing something new but also includes bringing that innovation into the market place and using it to deliver products and services to consumers.

Table 4.1 reveals that $19,5 \%$ of the respondents displayed an adequate ability for creativity, $22,1 \%$ a moderate ability and $58,4 \%$ a lack of ability. Combining adequate and moderate ability categories, reflects that $41,6 \%$ of the participants had an ability to be creative while the majority $(58,4 \%)$ lacks the ability to be creative.

\subsubsection{Calculated risk taking}

According to Wickham (2004), entrepreneurs are risk takers. They take calculated risks; this means that risks are taken after the entrepreneur has taken a careful look at all factors and thereafter decide if the chances to succeed are favourable. He also indicates that an entrepreneur faces different types of risks in his or her life, such as: financial risks, career risk, health risks, and the risk of family relationship.

Table 4.1 illustrates the results obtained from grade ten learners tested for calculated risk taking. The table reflects that $30,4 \%$ of the respondents tested, had an adequate ability for calculated risk taking, $23,8 \%$ a moderate ability while $45,8 \%$ showed a lack of ability to take calculated risks. Combining the adequate and moderate categories to evaluate the general ability of respondents concerning calculated risk taking, reflects that $54,2 \%$ of the participants showed abilities to take calculated risk while $45,8 \%$ lack the ability to take calculated risks.

\subsubsection{Drive and determination}

Nieman et al (2003) state that a real entrepreneur never gives up and he or she learns from previous mistakes. Hisrich and Peters (2002) support Nieman, stating: "if you really want to succeed, you must know there is always a price to pay, but also that you must not lose yourself in the process".

Nieman and Bennett (2002), Nieman et al (2003) and Niewenhuizen (2004) are of the opinion that entrepreneurs are driven by sound human relations, commitment to the enterprise, involvement in the enterprise, positive attitude and approach, passion, opportunity seeking, self-reliance, internal locus of control, ability to adapt, motivation to excel, and determination as well as persistence.

Table 4.1 reveals that only $13 \%$ of the respondents tested, displayed an adequate ability when measured in terms of drive and determination, $19,3 \%$ a moderate ability, and, unfortunately, (67,7\%) displayed a lack of ability. Summing up adequate and moderate ability categories indicates that $32.3 \%$ of grade ten learners had an ability for drive and determination whereas $67,7 \%$ showed a lack of ability for drive and determination.

The results obtained from those learners who participated in the study, only displayed ability for need for achievement and calculated risk taking. However, their performances in the other categories were below $50 \%$ which is an indication of lack of ability in respect of: need for autonomy; creative tendency; as well as, drive and determination. 


\subsection{Entrepreneurial qualities by subjects enrolled.}

\subsubsection{Need for achievement according to subjects enrolled}

Table 4.2 reflects that $30 \%$ of the grade ten learners who were enrolled for commercial subjects had an adequate ability for need for achievement, $19 \%$ had a moderate ability, while 51\% lacked the ability to achieve. Of the grade ten learners who were enrolled for non-commercial subjects, $36 \%$ had an adequate ability for need for achievement, $20 \%$ had a moderate ability, and $44 \%$ lacked the ability for need for achievement. The table shows that learners who were not doing commercial subjects had a 7\% edge over the learners who were doing commercial subjects, when tested for need for achievement.

Table 4.2: Need for achievement by subjects enrolled

\begin{tabular}{|c|c|c|c|c|}
\hline Subjects enrolled & Adequate ability & Moderate ability & Lack of ability & Total \\
\hline Commercial & $290(30 \%)$ & $176(19 \%)$ & $488(51 \%)$ & $954(100 \%)$ \\
\hline Non-Commercial & $351(36 \%)$ & $197(20 \%)$ & $429(44 \%)$ & $977(100 \%)$ \\
\hline Total & $641(33 \%)$ & $373(19 \%)$ & $917(48 \%)$ & $1931(100 \%)$ \\
\hline
\end{tabular}

Source: Researcher's own findings

\subsubsection{Need for autonomy according to subjects enrolled}

The need for autonomy amongst grade ten learners according to subjects enrolled, as reflected in table 4.3 did not reveal significant differences. Four percent of all learners tested, showed an adequate ability for need for autonomy, 17\% a moderate ability, while the vast majority (80\%) had a lack of ability for need for autonomy.

Table 4.3: Need for autonomy according to subjects enrolled

\begin{tabular}{|c|c|c|c|c|}
\hline Subjects enrolled & Adequate ability & Moderate ability & Lack of ability & Total \\
\hline Commercial & $38(4 \%)$ & $152(16 \%)$ & $744(80 \%)$ & $934(100 \%)$ \\
\hline Non-commercial & $32(3.4 \%)$ & $164(17.3 \%)$ & $752(79.3 \%)$ & $948(100 \%)$ \\
\hline Total & $70(4 \%)$ & $316(17 \%)$ & $1496(79 \%)$ & $188(100 \%)$ \\
\hline
\end{tabular}

Source: Researcher's own findings

\subsubsection{Creative tendency by subjects enrolled}

Table 4.4 reflects that $15 \%$ of grade ten learners who were enrolled for commercial subjects had an adequate ability for creativeness; $20 \%$ had a moderate ability, while $65 \%$ lacked the ability for creative tendencies. Grade ten learners who were enrolled for non-commercial subjects outscored grade ten learners enrolled for commercial subjects by a small margin. Seventeen percent of those enrolled for non-commercial subjects managed to maintain an adequate ability score, while 19\% managed a moderate ability for creative tendencies. Comparing the two groups, the findings revealed that the differences in scores were rather insignificant with respondents enrolled for non-commercial subjects having a slight edge $(1 \%)$.

Table 4.4: Creative tendency by Subjects enrolled

\begin{tabular}{|c|c|c|c|c|}
\hline Subjects enrolled & Adequate ability & Moderate ability & Lack of ability & Total \\
\hline Commercial & $148(15 \%)$ & $189(20 \%)$ & $617(65 \%)$ & $954(100 \%)$ \\
\hline Non-Commercial & $164(17 \%)$ & $189(19 \%)$ & $624(64 \%)$ & $977(100 \%)$ \\
\hline Total & $312(16 \%)$ & $378(20 \%)$ & $1241(64 \%)$ & $1931(100 \%)$ \\
\hline
\end{tabular}

Source: Researcher's own findings 


\subsubsection{Calculated risk taking according to subjects enrolled}

Calculated risks taking amongst grade ten learners may vary according to the subjects they have enrolled for. Table 4.5 shows a summary of the relationship between calculated risks taking according to subjects enrolled. Table 4.5 reflects that $14 \%$ of the respondents enrolled for commercial subjects had an adequate ability to take risks while $12 \%$ who were not enrolled for commercial subjects had an adequate ability for calculated risk taking. Of the commercial group, $17 \%$ had a moderate calculated risk taking ability, while $18 \%$ of those learners who were not enrolled for commercial subjects had a moderate ability for calculated risk taking; $69 \%$ of the respondents enrolled for commercial subjects showed a lack of ability for calculated risks taking, while $70 \%$ of the non-commercial subject respondents also showed a lack of ability to take calculated risks.

Table 4.5: Calculated risks taking by Subject enrolled

\begin{tabular}{|c|c|c|c|c|}
\hline Subjects enrolled & Adequate ability & Moderate ability & Lack of ability & Total \\
\hline Commercial & $135(14 \%)$ & $162(17 \%)$ & $657(69 \%)$ & $954(100 \%)$ \\
\hline Non-Commercial & $121(12 \%)$ & $171(18 \%)$ & $685(70 \%)$ & $977(100 \%)$ \\
\hline Total & $256(13 \%)$ & $333(17 \%)$ & $1342(70 \%)$ & $1931(100 \%)$ \\
\hline
\end{tabular}

Source: Researcher's own findings

\subsubsection{Drive and determination by subjects enrolled}

Table 4.6 shows a summary of the relationship between drive and determination according to subjects enrolled. Table 4.6 reflects that $13 \%$ of both respondents enrolled for commercial subjects and those not enrolled for commercial subjects had an adequate ability for drive and determination. However, $20 \%$ of the learners enrolled for commercial subjects had a moderate ability for drive and determination which gave them a $2 \%$ edge over those learners who were not enrolled for commercial subjects, with $18 \%$ of the non-commercial group having a moderate ability. Sixty seven percent of the respondents enrolled for commercial subjects had a lack of ability for drive and determination, while $69 \%$ of the noncommercial subject respondents also showed a lack of ability for drive and determination.

Table 4.6: Drive and Determination by subjects enrolled

\begin{tabular}{|c|c|c|c|c|}
\hline Subjects enrolled & Adequate ability & Moderate ability & Lack of ability & Total \\
\hline Commercial & $122(13 \%)$ & $194(20 \%)$ & $638(67 \%)$ & $954(100 \%)$ \\
\hline non-Commercial & $129(13 \%)$ & $179(18 \%)$ & $669(69 \%)$ & $977(100 \%)$ \\
\hline Total & $251(13 \%)$ & $373(19 \%)$ & $1307(68 \%)$ & $1931(100 \%)$ \\
\hline
\end{tabular}

Source: Researcher's own findings

\subsection{Cross tabulation of demographic information}

Table 4.7 indicates the responses obtained from male and female grade ten learners who were enrolled for commercial subjects and those who were not enrolled for commercial subjects. The table reflects that $47.7 \%$ of the male respondents were doing commercial subjects, while $52.3 \%$ were not enrolled for commercial subjects. Females who were enrolled for commercial subjects showed a larger percentage amounting to $51.0 \%$ as compared to those who were not enrolled for commercial subjects, $49.0 \%$. 
Table 4.7: Subjects enrolled by Gender

\begin{tabular}{|lll|c|c|c|}
\hline & & \multicolumn{2}{|c|}{ Gender } & \multirow{2}{*}{ Total } \\
\cline { 3 - 5 } & & Male & Female & \\
\hline \multirow{3}{*}{ Subjects enrolled } & Commercial & Count & 451 & 503 & 954 \\
& & $\%$ within Gender & $47.7 \%$ & $51.0 \%$ & $49.4 \%$ \\
\cline { 2 - 4 } & \multirow{2}{*}{ Non commercial } & Count & 494 & 483 & 977 \\
& & $\%$ within Gender & $52.3 \%$ & $49.0 \%$ & $50.6 \%$ \\
\hline \multirow{2}{*}{ Total } & Count & 945 & 986 & 1931 \\
& & \% within Gender & $100.0 \%$ & $100.0 \%$ & $100.0 \%$ \\
\hline
\end{tabular}

\section{Source: Own Research}

From an age perspective, table 4.8 provides information based on the age categories of grade ten learners who were enrolled for commercial and non-commercial subjects. In the age category 13 to 15 , only $29.6 \%$ of the respondents were enrolled for commercial subjects, while the vast majority, $70.4 \%$ were enrolled for non-commercial subjects. In the 16 to 18 age group $49.3 \%$ were enrolled for commercial subjects, while $50.7 \%$ were enrolled for non-commercial subjects. In the age group 19 and above, $54.8 \%$ of the respondents were enrolled for commercial, while $45.2 \%$ of the participants in this age group were not enrolled for commercial subjects.

Table 4.8: Subjects enrolled by Age group

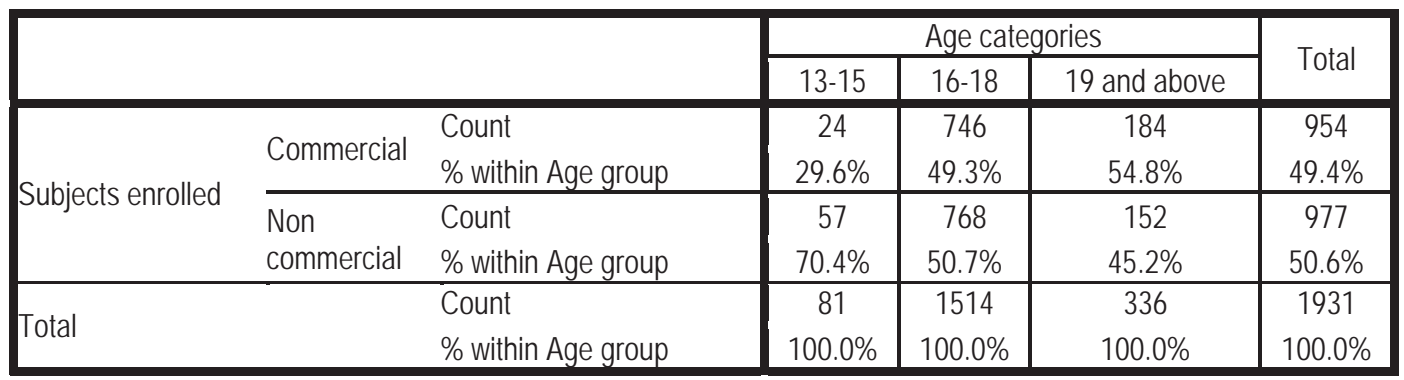

\section{Source: Own Research}

\section{Conclusion}

Identifying, assessing, and comparing the entrepreneurial qualities amongst grade ten learners in the CDM of Limpopo Province revealed that most of the learners did not perform well regarding need for autonomy, creative tendency as well as drive and determination. Of the five entrepreneurial quality categories, learners performed well only on need for achievement and calculated risk taking. The areas in which they performed poor are an indication of their lack of entrepreneurial qualities which need to be addressed at an early stage. Since the research was voluntary, the results shows that the grade ten male learners who were not enrolled for commercial subjects (52.3\%) were more actively involved in the research as compared to male counterparts who were enrolled for commercial subjects (47.7\%). The female grade ten learners, who were enrolled for commercial subjects, represented $51 \%$ of the female participants while their counterparts who were not enrolled for commercial subjects represented $49 \%$ of the female participants. An age comparison reflected that the younger learners in the age category 13 to 15, who were enrolled for commercial subjects, represented only $29.6 \%$, while the vast majority in the same age group who were not enrolled for commercial subjects represented $70.4 \%$ of the respondents. Learners in the age group 16 to 18 enrolled for commercial subjects, represented $49.3 \%$ of the participants, while those who were not enrolled for commercial subjects represented $50.7 \%$. However, in the age category 19 and above, $54.8 \%$ of the learners were enrolled for commercial subject, whereas the participation of non-commercial learners constituted $42.2 \%$. 


\section{Recommendation}

Students should be encouraged to follow the commercial stream and their teachers should endeavour to discourage the traditional way of thinking that commercial subjects are for the learners with low intellectual capacity and motivate them by providing them with the success stories of the entrepreneurs around their Province. Both parents and teachers must build confidence among learners by convincing them that commercial subjects will equip and prepare them to become independent, provide them with knowledge on how to construct a business plan to kick-start a business, and become successful in life without depending and blaming others for their failure.

Nowadays, since many learners drop out from school due to different reasons such as age restriction, bad performance and family problems, the introduction of entrepreneurship education as a compulsory school subject within both commercial and non-commercial streams will gain support, because learners can use the knowledge they acquire from their secondary school experience to start a business to sustain themselves and to alleviating the government's burden for job creation. Likewise, unemployment and poverty could be reduced in the Capricorn District Municipality and throughout the Limpopo Province.

\section{References}

Albright, S.C, Wiston, W.L., \& Zappe, C. (2006). Data analysis and decision making: with Microsoft excel. Mason: Thomson SouthWestern.

Autio, E. (2007). Report on high-growth entrepreneurship. Global entrepreneurship monitor report. Babson College and London business school. Available: Http://www.gemconsortium.org (May 10, 2010).

Baum JR, Locke, EA \& Smith KG. 2001. A Multidimensional model of venture growth. The Academy of Management Journal 44(2): 292303

Bjerk, B. (2007). Understanding entrepreneurship. Cheltenham: Edward Elgar.

Bolton, B., \& Thompson, J. 2004. Entrepreneurs talent, temperament and technique. (2nd ed). Burlington: Elsevier Butter WorthHeinemann.

Caird, S. (1992). Problems with identification of enterprise competencies and the implications for assessment and development. Management Education Development 23(1), 6-17.

Co, M.J, Groenewald, J, Mitchell, B, Nayager, T, Van Zyl, J, Visser, K, with Train, W \& Emanuel, B. (2006).Entrepreneurship: fresh perspective. Cape Town: Maskew Miller Longman.

Consortium for entrepreneurship education.(2004). National content standards for Entrepreneurship Education. From: http://www.entreed.org/standards_Toolkit/benefits.htm (February 11, 2010).

Crouch, S \& Housden, M. 2003. Marketing Research for Managers. (3rd ed). Burlington: Elsevier Butter Worth- Heinemann.

Davidsson, P. (2008). The entrepreneurship research challenge. Cheltenham: Edward Elgar. De Vos, A.S, Strydom, H, Fouche, C.E \& Delport, C.S.C. (2003). Research at grass root: for the social science and human profession.( 2nd ed). Pretoria: Van Schaik.

Hisrich, R.D \& Peters, M.P. (2002). Entrepreneurship. (5th ed). Boston: Iwin Mc Graw- Hill.

Katz, JA. 2003. The chronology and intellectual trajectory of American entrepreneurship education. Journal of business venturing 8(2): 283-300.

Limpopo Department of Education. (2010). Capricorn District circuit summary for 2010 grade 10 learners. From: http://www.edu.limpopo.gov.za (September 7, 2010).

Mason,J. (2001). Qualitative research. London :Sage publication Ltd.

Morris, M.H \& Kuratko, D.F. (2002). Corporate entrepreneurship. Florida: Hough College. Nieman, G. \& Bennett, A. (2002). Business management: a valued chain approach. Pretoria: Van Schaik Publisher.

Nieman, G. \& Bennett, A. 2002. Business Management: a valued chain approach. Pretoria: Van Schaik Publisher.

Nieman, G, Hough, J \& Niewenhuizen, C. (2003). Entrepreneurship: a South African perspective. Pretoria: Van Schaik.

Nieman, G \& Niewenhuizen, C. (2009). Entrepreneurship: a South African perspective. Pretoria: Van Schaik.

Nieuwenhuizen, C. (2004). Basics of entrepreneurship. Cape Town: Juta \& Co.Ltd.

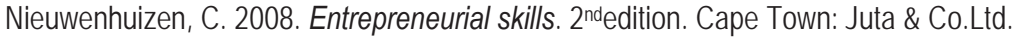

Reynolds, P.D, Bygrave W.D \& Autio, E. (2003). Global entrepreneurship monitor, executive report 2003. USA: Babson \& London school of Economics.

Rwigema, H \& Venter, R. (2004). Advanced entrepreneurship. Cape Town: Oxford University Press.

Stokes, D \& Wilson, N. 2010a. entrepreneurship and marketing education: time for the road less travelled? Journal of entrepreneurship and innovation management 11(1):95-108.

Timmons, J.A \& Spinelli, S. (2006). New venture creation: entrepreneurship for the 21st century. (7th ed). Boston: McGraw-Hill International.

Van Aardt, I, Hewitt, M, Bendeman, H, Bezuidenhout, S, Janse van Rensburg, L, Naidoo, P, Van Aardt, C, Van der Bank, J \& Visser, T. (2011). Entrepreneurship and new venture management. (4th ed). Cape Town: Oxford University Press.

Venter, R, Ubarn, B \& Rwigema, H. (2008). Entrepreneurship: theory in practice. (2nd ed). Cape Town: Oxford University Press. 
Welman, P.C, Kruger, F \& Mitchell, B. (2005). Research methodology. (3rd ed). Cape Town: Oxford University Press.

Wickham, P.A. (2001). Strategic entrepreneurship: a decision-making approach to new venture creation and management. (2nd ed). England: Printice Hall.

Wickham, P.A. (2004). Strategic entrepreneurship. (3rd ed) . England: Printice Hall.

Wiid, J. \& Diggines, C. (2009). Marketing research. Cape Town: Juta \& Co.Ltd. 